\title{
Thiomicrospira arctica sp. nov. and Thiomicrospira psychrophila sp. nov., psychrophilic, obligately chemolithoautotrophic, sulfur-oxidizing bacteria isolated from marine Arctic sediments
}

Correspondence Thorsten Brinkhoff t.brinkhoff@icbm.de

\author{
Katrin Knittel, ${ }^{1}$ Jan Kuever, ${ }^{1} \dagger$ Anke Meyerdierks, ${ }^{1}$ Ruth Meinke, ${ }^{1}$ \\ Rudolf Amann ${ }^{1}$ and Thorsten Brinkhoff ${ }^{1,2}$
${ }^{1}$ Max-Planck-Institute for Marine Microbiology, Celsiusstraße 1, D-28359 Bremen, Germany von Ossietzky Straße 9-11, D-26129 Oldenburg, Germany \\ ${ }^{2}$ Institute for Chemistry and Biology of the Marine Environment, University of Oldenburg, Carl
}

\begin{abstract}
Two psychrophilic, chemolithoautotrophic, sulfur-oxidizing bacteria were isolated from marine Arctic sediments sampled off the coast of Svalbard with thiosulfate as the electron donor and $\mathrm{CO}_{2}$ as carbon source. Comparative analysis of $16 \mathrm{~S}$ rRNA gene sequences suggested that the novel strains, designated SVAL-D ${ }^{\top}$ and SVAL- $E^{\top}$, represent members of the genus Thiomicrospira. Further genotypic (DNA-DNA relatedness, DNA G +C content) and phenotypic characterization revealed that the strains represent members of two novel species. Both organisms are obligately autotrophic and strictly aerobic. Nitrate was not used as an electron acceptor. Chemolithoautotrophic growth was observed with thiosulfate, tetrathionate and sulfur. The temperature limits for growth of both strains were between $-2{ }^{\circ} \mathrm{C}$ and $20.8^{\circ} \mathrm{C}$, with optima of $11.5-13 \cdot 2^{\circ} \mathrm{C}\left(\mathrm{SVAL}-\mathrm{E}^{\mathrm{T}}\right)$ and $14 \cdot 6-15 \cdot 4^{\circ} \mathrm{C}\left(\mathrm{SVAL}-\mathrm{D}^{\mathrm{T}}\right)$, which is about $13-15^{\circ} \mathrm{C}$ lower than the optima of all other recognized Thiomicrospira species. The maximum growth rate on thiosulfate at $14^{\circ} \mathrm{C}$ was $0.14 \mathrm{~h}^{-1}$ for strain SVAL-E and $0.2 \mathrm{~h}^{-1}$ for strain SVAL-D'. Major fatty acids of SVAL-D $D^{\top}$ are $C_{16: 1}, C_{18: 0}$ and $C_{16: 0}$, and those of SVAL-E ${ }^{\top}$ are $C_{16: 1}, C_{18: 1}$, $C_{16: 0}$ and $C_{14: 1}$. Cells of SVAL-D ${ }^{\top}$ and SVAL-E $E^{\top}$ are rods, like those of their closest relatives. To our knowledge the novel strains are the first psychrophilic, chemolithoautotrophic, sulfur-oxidizing bacteria so far described. The names Thiomicrospira arctica sp. nov. and Thiomicrospira psychrophila sp. nov. are proposed for SVAL-E ${ }^{\top}\left(=\right.$ ATCC $700955^{\top}=$ DSM $\left.13458^{\top}\right)$ and SVAL-D ${ }^{\top}\left(=\right.$ ATCC $700954^{\top}=$ DSM $\left.13453^{\top}\right)$, respectively.
\end{abstract}

Most of the sea floor is at temperatures below $4{ }^{\circ} \mathrm{C}$ (Levitus \& Boyer, 1994) and many bacteria living in this habitat are well adapted to the low temperature in their environment. Bacteria with very different metabolic properties have been isolated from cold marine sediments and their characterization has revealed that they were either psychrophilic or psychrotolerant (Knoblauch et al., 1999; Rüger et al., 2000;

Published online ahead of print on 22 October 2004 as DOI 10.1099/ ijs.0.63362-0.

†Present address: Bremen Institute for Materials Testing, Foundation Institute for Materials Science, Paul-Feller-Straße 1, D-28199 Bremen, Germany.

Abbreviation: SOB, sulfur-oxidizing bacteria.

The GenBank/EMBL/DDBJ accession numbers for the 16S rRNA gene sequences of $T$. arctica SVAL-E ${ }^{\top}$ and $T$. psychrophila SVAL-D ${ }^{\top}$ are respectively AJ404731 and AJ404732.

Micrographs of cells of strains SVAL-D ${ }^{\top}$ and SVAL-E ${ }^{\top}$ are available as supplementary material in IJSEM Online.
Humphry et al., 2001). Psychrophilic sulfur-oxidizing bacteria (SOB), however, have been relatively scarcely studied and little is known regarding their occurrence and diversity. Within a $16 \mathrm{~S}$ rRNA gene sequence clone library from organisms from permanently cold marine sediments, Ravenschlag et al. (1999) found that about $18 \%$ of all clones were related to symbiotic or free-living $\mathrm{SOB}$ of the $\gamma$-Proteobacteria. Mats of Beggiatoa species were described for cold seeps (e.g. Barry et al., 1996), but it is unknown whether these species are psychrophilic. Teske et al. (2000) reported that SOB from cold deep-sea sediments and from hydrothermal vent systems show habitat-related differences in growth temperature, but the temperature optima of these isolates were not determined.

We isolated two new SOB strains from Arctic sediments sampled off the coast of Svalbard. These strains are phylogenetically affiliated with members of the genus Thiomicrospira within the $\gamma$-Proteobacteria. Thiomicrospira species are obligately chemolithoautotrophic SOB, which have been 
detected in different habitats worldwide. They have been found in several marine sediments, in intertidal mudflats and a continental shelf sediment, in hydrothermal vent systems, and also in hypersaline ponds, a saline spring and a freshwater pond (e.g. Kuenen \& Veldkamp, 1972; Ruby \& Jannasch, 1982; Jannasch et al., 1985; Wood \& Kelly, 1993; Brinkhoff \& Muyzer, 1997). As indicated by molecular biological and microbiological studies, members of this genus appear to be ecologically significant at hydrothermal vent sites (Muyzer et al., 1995; Brinkhoff et al., 1999c), whereas in intertidal mudflat habitats Thiomicrospira strains have been found in much lower abundances than other SOB (Brinkhoff et al., 1998).

Marine arctic sediments were sampled off the coast of Spitsbergen (Svalbard) in July 1998. Strain SVAL-D ${ }^{\mathrm{T}}$

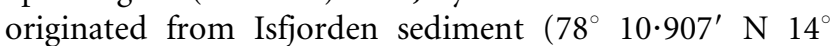
$34 \cdot 124^{\prime}$ E; water depth $246 \mathrm{~m}$ ) and strain SVAL-E $\mathrm{E}^{\mathrm{T}}$ from Jonsfjorden sediment $\left(78^{\circ} 32 \cdot 616^{\prime} \mathrm{N} 12^{\circ} 18 \cdot 075^{\prime} \mathrm{E}\right.$; water depth $168 \mathrm{~m}$ ). The in situ temperature was around $0{ }^{\circ} \mathrm{C}$ at both sampling sites. Strains SVAL-D ${ }^{\mathrm{T}}$ and SVAL-E ${ }^{\mathrm{T}}$ were obtained from enrichment cultures inoculated with mud samples of the upper sediment layer $(0-0.5 \mathrm{~cm}$ depth). The medium (TP) used and the isolation procedure were the same as described by Brinkhoff et al. (1999a), with the exception that the cultures were incubated at $4{ }^{\circ} \mathrm{C}$.

Routine cultivation of the isolates, utilization of different substrates and determination of salinity optimum and range were performed in $15 \mathrm{ml}$ tubes containing $5 \mathrm{ml} \mathrm{TP}$ medium or in $50 \mathrm{ml}$ tubes containing $20 \mathrm{ml} \mathrm{TP}$ medium at $4{ }^{\circ} \mathrm{C}$. Large-scale cultivation of strains SVAL- $\mathrm{D}^{\mathrm{T}}$ and SVAL$\mathrm{E}^{\mathrm{T}}$ was performed in a chemostat at $4{ }^{\circ} \mathrm{C}$ and cultivation of Thiomicrospira chilensis DSM $12352^{\mathrm{T}}$ was performed at $22{ }^{\circ} \mathrm{C}$ for subsequent analysis of fatty acids, determination of the $\mathrm{G}+\mathrm{C}$ content, DNA-DNA hybridization experiments and protein analysis. In this regard, 3 and 201 glass carboys were supplied with medium containing $40 \mathrm{mM}$ thiosulfate; the $\mathrm{pH}$ was monitored by a sterilized $\mathrm{pH}$ electrode (Ingold) and readjusted by titration with $\mathrm{Na}_{2} \mathrm{CO}_{3}$ $(1 \mathrm{M})$ to $\mathrm{pH} 7 \cdot 5$ through a personal computer program controlling a peristaltic pump. The program was developed by Volker Meyer at the Max-Planck-Institute for Marine Microbiology in Bremen. The chemostat was aerated with sterile pressurized air through sparging devices. The maximum growth rates for strains SVAL-D ${ }^{\mathrm{T}}$ and SVAL- $\mathrm{E}^{\mathrm{T}}$ in TP medium were determined in well-aerated cultures at $14^{\circ} \mathrm{C}$, by total 4',6-diamidino-2-phenylindole (DAPI) cell counts (Porter \& Feig, 1980).

An estimate of the optimal $\mathrm{pH}$ value and the lowest and highest values tolerated by the isolates was obtained by using $\mathrm{TP}$ medium adjusted to different initial $\mathrm{pH}$ values (in steps of 0.5 ) and supplied with $\mathrm{pH}$ indicators covering different $\mathrm{pH}$ ranges (bromocresol green, $3 \cdot 8-5 \cdot 4$; bromocresol purple, $5 \cdot 2-6 \cdot 8$; bromothymol blue, $6 \cdot 0-7 \cdot 5$; phenol red, 6.8-8.4; phenolphthalein, $8 \cdot 2-9 \cdot 8$ ). The $\mathrm{pH}$ range for growth was determined by screening for acidification on the basis of colour change of the $\mathrm{pH}$ indicator. For strain
SVAL- $\mathrm{E}^{\mathrm{T}}$ the optimum $\mathrm{pH}$ at $4{ }^{\circ} \mathrm{C}$ was additionally determined in a chemostat by measuring the oxygen turnover rates at different $\mathrm{pH}$ values between $\mathrm{pH} 6$ and 9 in steps of $0 \cdot 5$. The experiment was started after the chemostat reached equilibrium. After the substrate supply was stopped, the medium was saturated with oxygen. Aeration of the chemostat was then stopped and the first $\mathrm{pH}$ value was adjusted. Substrate supply was switched on and the decrease of oxygen was measured. After oxygen concentration reached $0 \%$, the substrate supply was switched off, the chemostat was aerated and the next $\mathrm{pH}$ value was adjusted. The decrease of oxygen at different $\mathrm{pH}$ values was plotted against time and the gradient of the straight line in the range between 20 and $80 \%$ oxygen saturation was determined by linear regression. This gradient was plotted against the $\mathrm{pH}$ values and the second-order polynomial was regressed. The $\mathrm{pH}$ optimum was determined from the curve obtained. Optimal growth temperature was determined in a thermally insulated aluminium block, which was heated electrically to $32{ }^{\circ} \mathrm{C}$ at one end and cooled to $-3{ }^{\circ} \mathrm{C}$ with a refrigerated circulation thermostat at the other end. The block contained 30 rows of four holes, so that samples could be incubated simultaneously at temperature intervals of $0.5{ }^{\circ} \mathrm{C}$ with a maximum of four replicates. The temperature limits of growth were established by screening for acidification for 30 days. The optimal growth temperature was determined within $36-48 \mathrm{~h}$ following inoculation. The $\mathrm{Na}^{+}$requirement and the utilization of inorganic and organic electron donors, including growth on hydrogen, and tests for anaerobic growth were carried out as described by Brinkhoff et al. (1999a).

Analyses of cellular fatty acid composition and respiratory lipoquinones were performed at the German Collection of Microorganisms and Cell Cultures (DSMZ, Braunschweig, Germany) using standard procedures (Tindall, 1990a, b). Determination of the $\mathrm{G}+\mathrm{C}$ content and DNA-DNA hybridization experiments were also performed at the DSMZ, and as described by Brinkhoff et al. (1999a). For protein analysis cell pellets were suspended in SDS sample buffer [0.35 mM Tris/HCl, pH 6.8,36\% (v/v) glycerol, $10 \%(\mathrm{w} / \mathrm{v})$ SDS, $9 \cdot 3 \%(\mathrm{w} / \mathrm{v})$ DTT, $0 \cdot 012 \%(\mathrm{w} / \mathrm{v})$ bromophenol blue], boiled and cooled on ice. Cell lysates were cleared by centrifugation at 14000 r.p.m. for $1 \mathrm{~min}$. The supernatant was separated on a $7 \cdot 5 \%$ denaturing SDS-polyacrylamide minigel according to the method of Laemmli (1970). Proteins were stained using Coomassie brilliant blue. PCR amplification of almost complete 16S rRNA genes, purification of PCR products and subsequent sequencing analysis were performed according to Brinkhoff \& Muyzer (1997). Sequence data were analysed with the ARB software package (Ludwig et al., 2004). A phylogenetic tree was calculated by maximum-likelihood analysis with different sets of filters. For tree calculation, only full-length sequences ( $>1300 \mathrm{bp}$ ) were considered.

Phylogenetic analysis of the 16S rRNA gene sequences of SVAL-D ${ }^{\mathrm{T}}$ and SVAL- $\mathrm{E}^{\mathrm{T}}$ demonstrated close affiliation with 


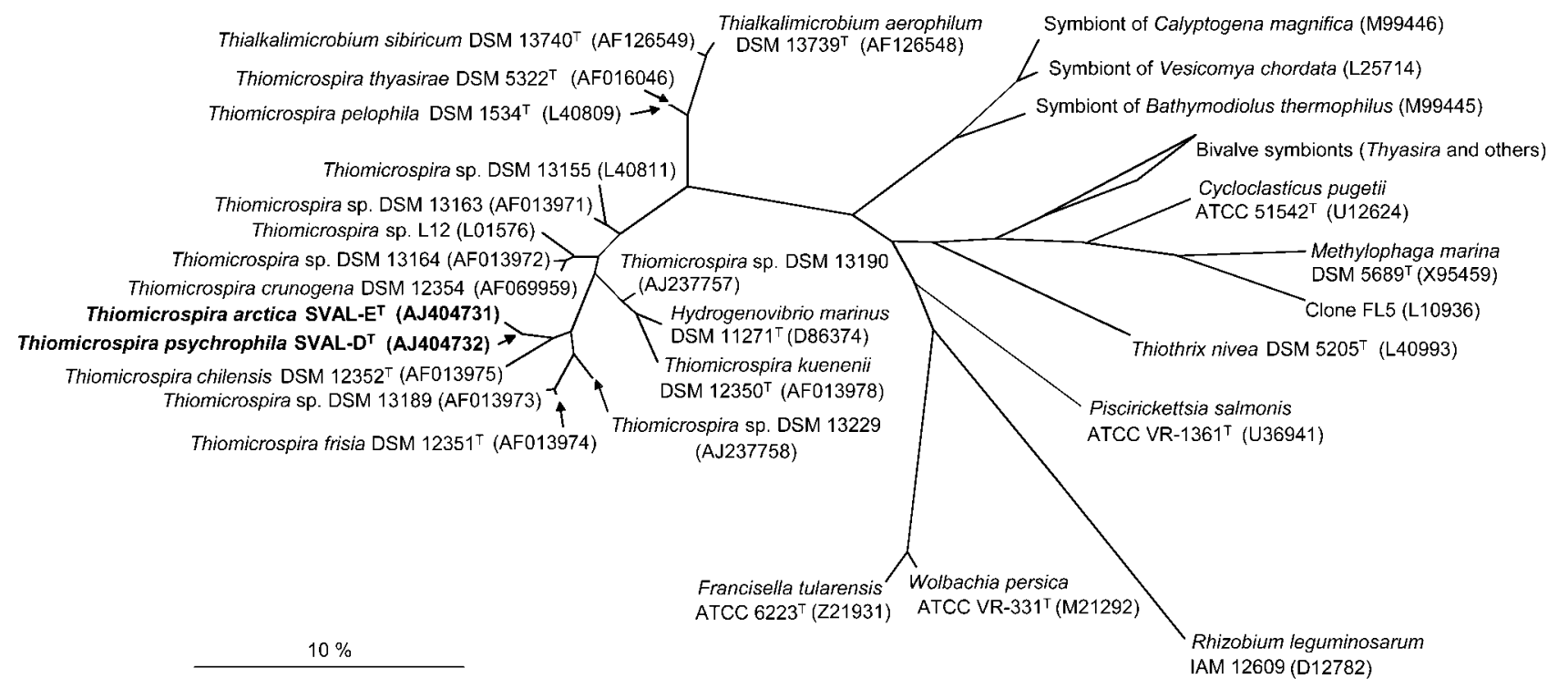

Fig. 1. Maximum-likelihood tree showing the affiliation of Thiomicrospira psychrophila sp. nov. SVAL-D ${ }^{\top}$ and Thiomicrospira arctica sp. nov. SVAL-E ${ }^{\top}$ to other Thiomicrospira species and selected reference sequences of the $\gamma$-Proteobacteria. Rhizobium leguminosarum was used as the outgroup. The tree is based on nearly complete 16S rRNA gene sequences. Bar, $10 \%$ estimated sequence divergence.

the genus Thiomicrospira (Fig. 1). Sequence similarity between the closest described relative $T$. chilensis DSM $12352^{\mathrm{T}}$ and strains SVAL-D ${ }^{\mathrm{T}}$ and SVAL-E ${ }^{\mathrm{T}}$ was 96.9 and $96 \cdot 1 \%$, respectively. Sequence similarity between SVAL-D ${ }^{\mathrm{T}}$ and SVAL-E ${ }^{\mathrm{T}}$ was $99.2 \%$, indicating that the two isolates belong to one species (Stackebrandt \& Goebel, 1994). However, DNA-DNA hybridization analysis with these organisms as well as with T. chilensis DSM $12352^{\mathrm{T}}$ revealed values below $70 \%(49 \cdot 2 \%$ DNA-DNA relatedness between SVAL-D ${ }^{\mathrm{T}}$ and SVAL-E ${ }^{\mathrm{T}}, 19 \cdot 9 \%$ between T. chilensis DSM $12352^{\mathrm{T}}$ and SVAL-E ${ }^{\mathrm{T}}$ and $19 \cdot 2 \%$ between T. chilensis DSM $12352^{\mathrm{T}}$ and SVAL-D ${ }^{\mathrm{T}}$ ). According to Wayne et al. (1987), the phylogenetic definition of a species generally includes strains with greater than $70 \%$ DNA-DNA relatedness. Thus, strains SVAL-D ${ }^{\mathrm{T}}$ and SVAL-E $\mathrm{E}^{\mathrm{T}}$ are clearly distinguishable from recognized Thiomicrospira species and from each other. Cells of strains SVAL-D ${ }^{\mathrm{T}}$ and SVAL-E ${ }^{\mathrm{T}}$ appear as single rods (see supplementary figure in IJSEM Online), like those of Thiomicrospira frisia DSM $12351^{\mathrm{T}}$ and $T$. chilensis DSM $12352^{\mathrm{T}}$, as well as those of the two strains Thiomicrospira sp. DSM 13189 and Thiomicrospira sp. DSM 13229. These organisms form a phylogenetic subcluster within the genus Thiomicrospira (Fig. 1), indicating a common ancestor for the rod-shaped morphology. Cells of strains SVAL-D ${ }^{\mathrm{T}}$ and SVAL- $\mathrm{E}^{\mathrm{T}}$ showed reduced levels of motility and were Gram-negative and spore formation was absent. Both strains were strictly aerobic and grew autotrophically on thiosulfate, tetrathionate and sulfur, but not on sulfite, thiocyanate or formate. Growth of strain SVAL-D ${ }^{\mathrm{T}}$ on thiosulfate lowered the $\mathrm{pH}$ to $5 \cdot 5$, whereas strain SVAL-E ${ }^{\mathrm{T}}$ lowered the $\mathrm{pH}$ to $5 \cdot 1$. Intermediate formation of elemental sulfur was observed with solid and liquid media. No growth occurred in TP medium supplemented with any of the organic substrates tested. Oxidation of thiosulfate was not inhibited by any of the organic substrates, except by acetate. Addition of vitamin B12 enhanced growth, but was not essential for growth. For strains SVAL-D ${ }^{\mathrm{T}}$ and SVAL-E $\mathrm{E}^{\mathrm{T}}$ growth was observed between $\mathrm{pH} 6 \cdot 5$ and $9 \cdot 0 . \mathrm{SVAL}^{\mathrm{T}} \mathrm{D}^{\mathrm{T}}$ and SVAL-E $\mathrm{E}^{\mathrm{T}}$ were able to grow at $\mathrm{Na}^{+}$concentrations between 40 and $1240 \mathrm{mM}$. For both isolates a $\mathrm{Na}^{+}$concentration of $250 \mathrm{mM}$ resulted in optimal growth. The optimum $\mathrm{pH}$ for SVAL-D ${ }^{\mathrm{T}}$ was $7 \cdot 5-8 \cdot 5$. The optimum $\mathrm{pH}$ for $\mathrm{SVAL}^{\mathrm{T}} \mathrm{E}^{\mathrm{T}}$ was $7 \cdot 5-8 \cdot 0$ as determined by indicator colour change, and $7 \cdot 3-7 \cdot 6$ as determined in the chemostat experiment by measuring the oxygen turnover rates at different $\mathrm{pH}$ values. The $\mathrm{G}+\mathrm{C}$ contents of strains SVAL-D ${ }^{\mathrm{T}}$ and SVAL-E $\mathrm{E}^{\mathrm{T}}$ were $42 \cdot 5$ and $42 \cdot 4 \mathrm{~mol} \%$, respectively. Ubiquinone 8 was the sole respiratory lipoquinone detected in both strains. This quinone is present in all Thiomicrospira species investigated so far (Brinkhoff et al., 1999b).

The cellular fatty acid profiles of SVAL-D ${ }^{\mathrm{T}}$ and SVAL-E ${ }^{\mathrm{T}}$ were identical with respect to the presence of specific fatty acids, but differed in their relative amounts (Table 1). The profile of $T$. chilensis DSM $12352^{\mathrm{T}}$ was also similar, but three fatty acids found for the novel strains could not be detected $\left(\mathrm{C}_{12: 0}, \mathrm{C}_{14: 0}, \mathrm{C}_{14: 1}\right)$. The major fatty acid in all three strains was palmitoleic acid $\left(\mathrm{C}_{16: 1} ; 39 \cdot 1-43 \cdot 4 \%\right.$ of the total cellular fatty acids). Furthermore, high levels of palmitic acid $\left(\mathrm{C}_{16: 0}\right)$ were found in all three species. Whereas high levels of stearic acid $\left(\mathrm{C}_{18: 0}\right)$ and low levels of $\mathrm{C}_{18: 1}$ fatty acids were found in SVAL-D ${ }^{\mathrm{T}}(32 \cdot 0$ and $3 \cdot 2 \%$, respectively), the opposite was detected for SVAL-E ${ }^{\mathrm{T}}(0 \cdot 8$ 
Table 1. Cellular fatty acid composition of Thiomicrospira species

Strains: 1, T. chilensis DSM $12352^{\mathrm{T}}$ (growth at $22^{\circ} \mathrm{C}$ ); 2, T. psychrophila sp. nov. SVAL-D ${ }^{\mathrm{T}}$ (growth at $4{ }^{\circ} \mathrm{C}$ ); 3 , T. arctica sp. nov. SVAL-E ${ }^{\mathrm{T}}$ (growth at $4{ }^{\circ} \mathrm{C}$ ). Proportions of fatty acids are given as percentages of whole-cell fatty acids. ND, Not detected.

\begin{tabular}{|lcrr|}
\hline Fatty acid & $\mathbf{1}$ & $\mathbf{2}$ & $\mathbf{3}$ \\
\hline Saturated fatty acids & & & \\
$\mathrm{C}_{12: 0}$ & $\mathrm{ND}$ & $1 \cdot 6$ & $2 \cdot 4$ \\
$\mathrm{C}_{14: 0}$ & $\mathrm{ND}$ & $0 \cdot 5$ & $0 \cdot 8$ \\
$\mathrm{C}_{16: 0}$ & $18 \cdot 9$ & $9 \cdot 7$ & $12 \cdot 7$ \\
$\mathrm{C}_{18: 0}$ & $3 \cdot 5$ & $32 \cdot 0$ & $0 \cdot 8$ \\
Unsaturated fatty acids & & & \\
$\mathrm{C}_{12: 1}$ & $3 \cdot 4$ & $4 \cdot 5$ & $3 \cdot 2$ \\
$\mathrm{C}_{14: 1}$ & $\mathrm{ND}$ & $5 \cdot 0$ & $11 \cdot 6$ \\
$\mathrm{C}_{16: 1}$ & $43 \cdot 4$ & $40 \cdot 0$ & $39 \cdot 1$ \\
$\mathrm{C}_{18: 1}$ & $27 \cdot 8$ & $3 \cdot 2$ & $26 \cdot 5$ \\
Hydroxy fatty acids & & & \\
$\mathrm{C}_{10: 0} 3-\mathrm{OH}$ & $1 \cdot 7$ & $0 \cdot 7$ & $0 \cdot 4$ \\
$\mathrm{C}_{14: 1} 3-\mathrm{OH}^{*}$ & $2 \cdot 1$ & $2 \cdot 2$ & $1 \cdot 6$ \\
\hline
\end{tabular}

${ }^{\star}$ Classification uncertain.

and $26 \cdot 5 \%$ ). The fatty acids $\mathrm{C}_{16: 0}, \mathrm{C}_{16: 1}$ and $\mathrm{C}_{18: 1}$ are characteristic for most aerobic, Gram-negative bacteria, including Thiomicrospira-related genera (Nishihara et al., 1991). Protein patterns of SVAL-D ${ }^{\mathrm{T}}$ and SVAL-E $\mathrm{E}^{\mathrm{T}}$, which were grown under similar conditions, showed some differences, and were clearly different from the pattern of $T$. chilensis DSM $12352^{\mathrm{T}}$ (Fig. 2). Differences in fatty acid and protein patterns of SVAL-D ${ }^{\mathrm{T}}$ and SVAL- $\mathrm{E}^{\mathrm{T}}$ from those of T. chilensis DSM $12352^{\mathrm{T}}$ might partially be explained by differences in their cultivation conditions $\left(4^{\circ} \mathrm{C}\right.$ and $22^{\circ} \mathrm{C}$, respectively).

Temperature limits for growth of SVAL-D ${ }^{\mathrm{T}}$ and SVAL- $\mathrm{E}^{\mathrm{T}}$ were between $-2 \cdot 0$ and $20 \cdot 8^{\circ} \mathrm{C}$. The optimum growth temperature for strain SVAL-D ${ }^{\mathrm{T}}$ was between $14 \cdot 6$ and $15 \cdot 4^{\circ} \mathrm{C}$, and was even lower for strain SVAL-E ${ }^{\mathrm{T}}(11 \cdot 5-$ $13 \cdot 2^{\circ} \mathrm{C}$ ). A widely accepted definition for psychrophilic bacteria is that they have an optimal growth temperature below $15^{\circ} \mathrm{C}$, a maximum growth temperature of $20^{\circ} \mathrm{C}$ and the ability to grow at $0^{\circ} \mathrm{C}$ (Morita, 1975; Russell \& Hamamoto, 1998). According to this definition our novel strains are psychrophilic. Cells of strain SVAL-E ${ }^{\mathrm{T}}$, which were pre-incubated for 2 months at 10,14 and $20^{\circ} \mathrm{C}$, grew over a slightly broader temperature range $\left(-2 \cdot 0\right.$ to $\left.24^{\circ} \mathrm{C}\right)$ and also showed a higher optimum growth temperature $\left(14 \cdot 5-17 \cdot 3,15 \cdot 3-17 \cdot 6\right.$ and $\left.15 \cdot 7-17 \cdot 3^{\circ} \mathrm{C}\right)$. Phenotypic properties that distinguish strains SVAL- $\mathrm{E}^{\mathrm{T}}$ and SVAL-D ${ }^{\mathrm{T}}$ from recognized Thiomicrospira species are given in Table 2.

It is known that the ability of psychrophilic and psychrotolerant micro-organisms to grow at low but not moderate temperatures depends on adaptive changes in cellular

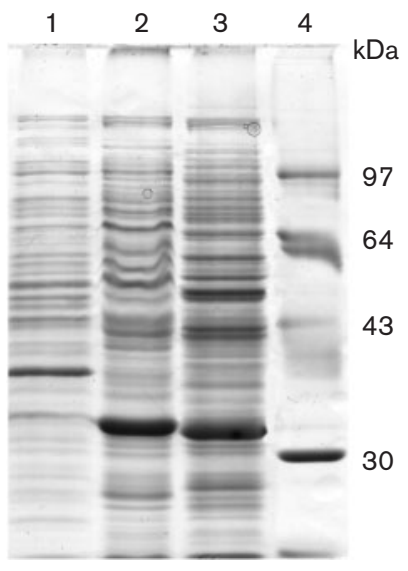

Fig. 2. SDS-PAGE of proteins of Thiomicrospira species. All strains were grown in a fermenter, T. chilensis DSM $12352^{\top}$ (lane 1 ) at $22^{\circ} \mathrm{C}$ and $T$. arctica sp. nov. SVAL-E ${ }^{\top}$ (lane 2) and T. psychrophila sp. nov. SVAL-D ${ }^{\top}$ (lane 3) at $4^{\circ} \mathrm{C}$. Lane 4 contains markers.

proteins and lipids (Gounot \& Russell, 1999). Changes in lipids can be genotypic or phenotypic and are important in regulating membrane fluidity and permeability. The upper growth temperature limit can result from the inactivation of a single enzyme type or system, including protein synthesis or energy generation (Russell, 1990). The present study demonstrates that the range of the worldwidedistributed genus Thiomicrospira is also extended to cold habitats. Thiomicrospira species appear to be adaptable to different environmental conditions and the main condition for their occurrence seems to be the presence of utilizable reduced sulfur compounds.

\section{Description of Thiomicrospira arctica sp. nov.}

Thiomicrospira arctica (arc'ti.ca. L. fem. adj. arctica from the Arctic, referring to the site where the type strain was isolated).

Cells are Gram-negative, motile and rod-shaped (0.5$0 \cdot 6 \times 1 \cdot 2-1 \cdot 5 \mu \mathrm{m})$. Strictly aerobic and grows autotrophically on thiosulfate, tetrathionate and sulfur, but not on sulfite or thiocyanate. Does not grow heterotrophically. When thiosulfate is used as the primary energy source small amounts of sulfur are produced. During growth on reduced sulfur compounds the $\mathrm{pH}$ decreases from neutrality to around $5 \cdot 1$. Autotrophic growth on thiosulfate occurs between $\mathrm{pH} 6.5$ and 9.0 and at temperatures of $-2 \cdot 0$ to $20 \cdot 8{ }^{\circ} \mathrm{C}$; optimum growth occurs at $\mathrm{pH} 7 \cdot 3-8 \cdot 0$ and at $11 \cdot 5-13 \cdot 2{ }^{\circ} \mathrm{C}$. The optimal $\mathrm{Na}^{+}$concentration for growth is $250 \mathrm{mM}$; growth is possible between $\mathrm{Na}^{+}$ concentrations of 40 and $1240 \mathrm{mM}$. Nitrate is not used as a terminal electron acceptor. On thiosulfate agar, cells produce yellow, smooth, entire colonies [mean diameter on $1 \%(\mathrm{w} / \mathrm{v})$ agar is $1 \mathrm{~mm}$ after $4-6$ weeks], in which sulfur is deposited and acid is produced. Ubiquinone Q-8 is present in the respiratory chain. Major fatty acids are $\mathrm{C}_{16: 1}$, 
Table 2. Phenotypic properties that differentiate $T$. arctica sp. nov. SVAL-E ${ }^{\top}$ and T. psychrophila sp. nov. SVAL-D ${ }^{\top}$ from phylogenetically related Thiomicrospira species

Strains: 1, T. pelophila DSM $1534^{\mathrm{T}} ; 2$, T. frisia DSM $12351^{\mathrm{T}} ; 3$, T. chilensis DSM $12352^{\mathrm{T}} ; 4$, T. arctica SVAL-E ${ }^{\mathrm{T}}$; 5, T. psychrophila SVAL-D ${ }^{\mathrm{T}}$. Data are from Kuenen \& Veldkamp (1972), Brinkhoff et al. (1999a, b) and this study.

\begin{tabular}{|c|c|c|c|c|c|}
\hline Character & 1 & 2 & 3 & 4 & 5 \\
\hline $\mathrm{G}+\mathrm{C}$ content $(\mathrm{mol} \%)$ & $45 \cdot 7$ & $39 \cdot 6$ & $49 \cdot 9$ & $42 \cdot 4$ & $42 \cdot 5$ \\
\hline Optimal pH & $7 \cdot 0$ & $6 \cdot 5$ & $7 \cdot 0$ & $7 \cdot 3-8 \cdot 0$ & $7 \cdot 5-8 \cdot 5$ \\
\hline $\mathrm{pH}$ range & $5 \cdot 6-9 \cdot 0$ & $4 \cdot 2-8 \cdot 5$ & $5 \cdot 3-8 \cdot 5$ & $6 \cdot 5-9 \cdot 0$ & $6 \cdot 5-9 \cdot 0$ \\
\hline Optimal temperature $\left({ }^{\circ} \mathrm{C}\right)$ & $28-30$ & $32-35$ & $32-37$ & $11 \cdot 5-13 \cdot 2$ & $14 \cdot 6-15 \cdot 4$ \\
\hline Optimal $\mathrm{Na}^{+}$concentration $(\mathrm{mM})$ & 470 & 470 & 470 & 250 & 250 \\
\hline
\end{tabular}

${ }^{\star}$ Only few cells showed motility.

$\mathrm{C}_{18: 1}, \mathrm{C}_{16: 0}$ and $\mathrm{C}_{14: 1}$. As determined by $16 \mathrm{~S}$ rRNA gene sequence analysis, Thiomicrospira arctica belongs to the $\gamma$-Proteobacteria and is closely related to previously described members of the genus Thiomicrospira.

The type strain is SVAL- $\mathrm{E}^{\mathrm{T}}$ (=ATCC $700955^{\mathrm{T}}=\mathrm{DSM}$ $13458^{\mathrm{T}}$ ). The $\mathrm{G}+\mathrm{C}$ content of the DNA is $42 \cdot 4 \mathrm{~mol} \%$. Isolated from marine Arctic sediments taken off the coast of Svalbard.

\section{Description of Thiomicrospira psychrophila sp. nov.}

Thiomicrospira psychrophila (psy.chro' phi.la. Gr. adj. psychros cold; Gr. adj. philos loving; N.L. fem. adj. psychrophila cold-loving).

Cells are Gram-negative, motile and rod-shaped $(0 \cdot 5-$ $0 \cdot 6 \times 1 \cdot 3-1 \cdot 7 \mu \mathrm{m})$. Strictly aerobic and grows autotrophically on thiosulfate, tetrathionate and sulfur, but not on sulfite or thiocyanate. Does not grow heterotrophically. When thiosulfate is used as the primary energy source small amounts of sulfur are produced. During growth on reduced sulfur compounds the $\mathrm{pH}$ decreases from neutrality to around $5 \cdot 5$. Autotrophic growth on thiosulfate occurs between $\mathrm{pH} 6.5$ and 9.0 and at temperatures of $-2 \cdot 0$ to $20 \cdot 8{ }^{\circ} \mathrm{C}$; optimum growth occurs at $\mathrm{pH} 7 \cdot 5-8 \cdot 5$ and at $14 \cdot 6-15 \cdot 4{ }^{\circ} \mathrm{C}$. The optimal $\mathrm{Na}^{+}$concentration for growth is $250 \mathrm{mM}$; growth is possible between $\mathrm{Na}^{+}$concentrations of 40 and $1240 \mathrm{mM}$. Nitrate is not used as a terminal electron acceptor. On thiosulfate agar, cells produce yellow, smooth, entire colonies [mean diameter on $1 \%(\mathrm{w} / \mathrm{v})$ agar is $1 \mathrm{~mm}$ after $4-6$ weeks], in which sulfur is deposited and acid is produced. Ubiquinone Q-8 is present in the respiratory chain. Major fatty acids are $\mathrm{C}_{16: 1}, \mathrm{C}_{18: 0}$ and $\mathrm{C}_{16: 0}$. As determined by $16 \mathrm{~S}$ rRNA gene sequence analysis, Thiomicrospira psychrophila belongs to the $\gamma$-Proteobacteria and is closely related to previously described members of the genus Thiomicrospira.
The type strain is SVAL-D ${ }^{\mathrm{T}}\left(=\mathrm{ATCC} 700954^{\mathrm{T}}=\mathrm{DSM}\right.$ $\left.13453^{\mathrm{T}}\right)$. The $\mathrm{G}+\mathrm{C}$ content of the DNA is $42 \cdot 5 \mathrm{~mol} \%$. Isolated from marine Arctic sediments taken off the coast of Svalbard.

\section{Acknowledgements}

We thank Daniela Lange for technical assistance, Heike Stevens for help with electron microscopy and Marko Remisch for mass cultivation. The project was supported by the Max-Planck-Society.

\section{References}

Barry, J. P., Greene, H. G., Orange, D. L., Baxter, C. H., Robison, B. H., Kochevar, R. E., Nybakken, J. W., Reed, D. L. \& McHugh, C. M. (1996). Biologic and geologic characteristics of cold seeps in Monterey Bay, California. Deep Sea Res Part I Oceanogr Res Pap 43, 1739-1755.

Brinkhoff, T. \& Muyzer, G. (1997). Increased species diversity and extended habitat range of sulfur-oxidizing Thiomicrospira spp. Appl Environ Microbiol 63, 3789-3796.

Brinkhoff, T., Santegoeds, C. M., Sahm, K., Kuever, J. \& Muyzer, G. (1998). A polyphasic approach to study the diversity and vertical distribution of sulfur-oxidizing Thiomicrospira species in coastal sediments of the German Wadden Sea. Appl Environ Microbiol 64, 4650-4657.

Brinkhoff, T., Muyzer, G., Wirsen, C. O. \& Kuever, J. (1999a). Thiomicrospira kuenenii sp. nov. and Thiomicrospira frisia sp. nov., two mesophilic obligately chemolithoautotrophic sulfur-oxidizing bacteria isolated from an intertidal mud flat. Int $J$ Syst Bacteriol 49, 385-392.

Brinkhoff, T., Muyzer, G., Wirsen, C. O. \& Kuever, J. (1999b). Thiomicrospira chilensis sp. nov., a mesophilic obligately chemolithoautotrophic sulfur-oxidizing bacterium isolated from a Thioploca mat. Int J Syst Bacteriol 49, 875-879.

Brinkhoff, T., Sievert, S. M., Kuever, J. \& Muyzer, G. (1999c). Distribution and diversity of sulfur-oxidizing Thiomicrospira spp. at a shallow-water hydrothermal vent in the Aegean Sea (Milos, Greece). Appl Environ Microbiol 65, 3843-3849. 
Gounot, A. M. \& Russell, N. J. (1999). Physiology of cold-adapted microorganisms. In Cold-Adapted Organisms, pp. 33-55. Edited by R. Margesin \& F. Schinner. New York: Springer.

Humphry, D. R., George, A., Black, G. W. \& Cummings, S. P. (2001). Flavobacterium frigidarium sp. nov., an aerobic, psychrophilic, xylanolytic and laminarinolytic bacterium from Antarctica. Int J Syst Evol Microbiol 51, 1235-1243.

Jannasch, H. W., Wirsen, C. O., Nelson, D. C. \& Robertson, L. A. (1985). Thiomicrospira crunogena sp. nov., a colorless sulfuroxidizing bacterium from a deep-sea hydrothermal vent. Int J Syst Bacteriol 35, 422-424.

Knoblauch, C., Sahm, K. \& Jorgensen, B. B. (1999). Psychrophilic sulfate-reducing bacteria isolated from permanently cold arctic marine sediments: description of Desulfofrigus oceanense gen. nov., sp. nov., Desulfofrigus fragile sp. nov., Desulfofaba gelida gen. nov., sp. nov., Desulfotalea psychrophila gen. nov., sp. nov. and Desulfotalea arctica sp. nov. Int J Syst Bacteriol 49, 1631-1643.

Kuenen, J. G. \& Veldkamp, H. (1972). Thiomicrospira pelophila, gen. n. sp. n., a new obligately chemolithotrophic colourless sulfur bacterium. Antonie van Leeuwenhoek 38, 241-256.

Laemmli, U. K. (1970). Cleavage of structural proteins during the assembly of the head of bacteriophage T4. Nature 227, 680-685.

Levitus, S. \& Boyer, T. (1994). World Ocean Atlas, vol. 4, Temperature. Washington, DC: US Department of Commerce.

Ludwig, W., Strunk, O., Westram, R. \& 29 other authors (2004). ARB: a software environment for sequence data. Nucleic Acids Res 32, 1363-1371.

Morita, R. Y. (1975). Psychrophilic bacteria. Bacteriol Rev 39, 144-167.

Muyzer, G., Teske, A., Wirsen, C. O. \& Jannasch, H. W. (1995). Phylogenetic relationships of Thiomicrospira species and their identification in deep-sea hydrothermal vent samples by denaturing gradient gel electrophoresis of $16 \mathrm{~S}$ rDNA fragments. Arch Microbiol 164, 165-172.

Nishihara, H., Igarashi, Y. \& Kodama, T. (1991). Hydrogenovibrio marinus gen. nov., sp. nov., a marine obligately chemolithoautotrophic hydrogen-oxidizing bacterium. Int $J$ Syst Bacteriol 41, $130-133$.
Porter, K. G. \& Feig, Y. S. (1980). The use of DAPI for identifying and counting aquatic microflora. Limnol Oceanogr 25, 943-948.

Ravenschlag, K., Sahm, K., Pernthaler, J. \& Amann, R. (1999). High bacterial diversity in permanently cold marine sediments. Appl Environ Microbiol 65, 3982-3989.

Ruby, E. G. \& Jannasch, H. W. (1982). Physiological characteristics of Thiomicrospira sp. strain L-12 isolated from deep-sea hydrothermal vents. J Bacteriol 149, 161-165.

Rüger, H. J., Fritze, D. \& Spröer, C. (2000). New psychrophilic and psychrotolerant Bacillus marinus strains from tropical and polar deep-sea sediments and emended description of the species. Int J Syst Evol Microbiol 50, 1305-1313.

Russell, N. J. (1990). Cold adaptation of microorganisms. Philos Trans R Soc Lond B Biol Sci 30, 595-611.

Russell, N. J. \& Hamamoto, T. (1998). Psychrophiles. In Extremophiles: Microbial Life in Extreme Environments, pp. 25-45. Edited by K. Horikoshi \& W. D. Grant. New York: Wiley.

Stackebrandt, E. \& Goebel, B. M. (1994). Taxonomic note: a place for DNA-DNA reassociation and 16S rRNA sequence analysis in the present species definition in bacteriology. Int J Syst Bacteriol 44, 846-849.

Teske, A., Brinkhoff, T., Muyzer, G., Moser, D. P., Rethmeier, J. \& Jannasch, H. W. (2000). Diversity of thiosulfate-oxidizing bacteria from marine sediments and hydrothermal vents. Appl Environ Microbiol 66, 3125-3133.

Tindall, B. J. (1990a). A comparative study of the lipid composition of Halobacterium saccharavorum from various sources. Syst Appl Microbiol 13, 128-130.

Tindall, B. J. (1990b). Lipid composition of Halobacterium lacusprofundi. FEMS Microbiol Lett 66, 199-202.

Wayne, L. G., Brenner, D. J., Colwell, R. R. \& 9 other authors (1987), Report of the ad hoc committee on reconciliation of approaches to bacterial systematics. Int J Syst Bacteriol 37, 463-464.

Wood, A. P. \& Kelly, D. P. (1993). Reclassification of Thiobacillus thyasiris as Thiomicrospira thyasirae comb. nov., an organism exhibiting pleomorphism in response to environmental conditions. Arch Microbiol 159, 45-47. 